\title{
Population dynamics of Anopheles gambiae s.l. in Bobo-Dioulasso city: bionomics, infection rate and susceptibility to insecticides
}

Roch K Dabiré ${ }^{*}$, Moussa Namountougou', Simon P Sawadogo ', Lassina B Yaro ${ }^{1}$, Hyacinthe K Toé ${ }^{1}$, Ali Ouari ${ }^{1}$, Louis-Clément Gouagna ${ }^{2}$, Frédéric Simard ${ }^{3}$, Fabrice Chandre ${ }^{4}$, Thierry Baldet ${ }^{5}$, Chris Bass ${ }^{6}$ and Abdoulaye Diabaté ${ }^{1}$

\begin{abstract}
Background: Historical studies have indicated that An. gambiae s.s. is the predominant malaria vector species in Bobo-Dioulasso the second biggest city of Burkina Faso (West Africa). However, over the last decade, An. arabiensis appears to be replacing An. gambiae s.s. as the most prevalent malaria vector in this urban setting. To investigate this species transition in more detail the present study aims to provide an update on the malaria vector composition in Bobo-Dioulasso, and also the Plasmodium infection rates and susceptibility to insecticides of the local An. gambiae s.l. population.
\end{abstract}

Methods: An entomological survey was carried out from May to December 2008 in Dioulassoba and Kodeni (central and peripheral districts respectively), which are representative of the main ecological features of the city. Sampling consisted of the collection of larval stages from water bodies, and adults by monthly indoor residual spraying (IRS) using aerosol insecticides. Insecticide susceptibility tests were performed using the WHO filter paper protocol on adults emerged from larvae. PCR was used to determine vector species and to identify resistance mechanisms $\left(k d r\right.$ and $\left.a c e-1^{R}\right)$. The Plasmodium infection rate was estimated by ELISA performed on female mosquitoes collected indoors by IRS.

Results: An. arabiensis was found to be the major malaria vector in Bobo-Dioulasso, comprising 50 to $100 \%$ of the vector population. The sporozoite infection rate for An. arabiensis was higher than An. gambiae s.s. at both Dioulassoba and Kodeni. An. gambiae s.I. was resistant to DDT and cross-resistant to pyrethroids at the two sites with higher levels of resistance observed in An. gambiae s.s. than An. arabiensis. Resistance to $0.1 \%$ bendiocarb was observed in the An. gambiae s.s. S form but not the M form or in An. arabiensis. The L1014F kdr mutation was detected in the two molecular forms of An. gambiae s.s. at varying frequencies (0.45 to 0.92), but was not detected in An. arabiensis, suggesting that other mechanisms are involved in DDT resistance in this species. The ace $-1^{R}$ mutation was only detected in the $S$ molecular form and was observed at the two sites at similar frequency (0.3).

Conclusions: Over the last ten years, An. arabiensis has become the major malaria vector in Bobo-Dioulasso city where it was formerly present only at low frequency. However, the ecological determinant that enhances the settlement of this species into urban and peri-urban areas of Bobo-Dioulasso remains to be clarified. The impact of the changing An. gambiae s.l. population in this region for vector control including resistance management strategies is discussed.

Keywords: Malaria, Anopheles gambiae s.l., An. arabiensis, Insecticide resistance, Bobo-Dioulasso, Burkina Faso

\footnotetext{
* Correspondence: dabire_roch@hotmail.com

${ }^{1}$ Institut de Recherche en Sciences de la Santé/Centre Muraz, 01 BP 390

Bobo-Dioulasso 01, Burkina Faso

Full list of author information is available at the end of the article
}

\section{Biomed Central}

(c) 2012 Dabire et al.; licensee BioMed Central Ltd. This is an Open Access article distributed under the terms of the Creative Commons Attribution License (http://creativecommons.org/licenses/by/2.0), which permits unrestricted use, distribution, and reproduction in any medium, provided the original work is properly cited. 


\section{Background}

Anopheles gambiae s.s. Giles and Anopheles arabiensis Patton are two of the most important malaria vector species in Africa. The two species are members of the An. gambiae species complex and are sympatric in many regions of the sub-Saharan tropical savannah [1]. Studies of the spatial distribution patterns of An. gambiae s.l. have shown that $A n$. arabiensis is distributed across East to West Africa [2,3] occurring in sympatry with the $A n$. gambiae $\mathrm{S}$ form in East Africa (where the $\mathrm{M}$ form is absent) and with both An. gambiae S and M forms in West Africa. In West Africa, although the two forms of $A n$. gambiae are found in sympatry with $A n$. arabiensis they exploit different ecological niches $[4,5]$. The $M$ form is found occupying flooded areas such as rice growing areas and human-made breeding sites in more arid savannahs, whereas the $S$ form is more rain-dependant and is mostly observed during the wet period of the year [5]. Although the distribution of An. arabiensis is also influenced by eco-climatic variations, this species can now be found invading urban areas possibly as a consequence of adaptation to human activities/environments. The recent utilisation of artificial breeding sites by $A n$. arabiensis has been documented in both East and West Africa [6-9]. In Burkina Faso previous studies showed that $A n$. arabiensis was the third most prevalent malaria vector species after $A n$. gambiae s.s. and An. funestus in western areas of the country [10-12] (Diabaté, unpublished) but was identified with similar frequency as the An. gambiae $\mathrm{M}$ form in central and eastern regions of the country (sudan-sahelian climate with moderate rainfall ranging from 600 to $1000 \mathrm{~mm}$ ) [9]. In western regions of the country dominated by Sudan climatic conditions with relatively abundant rainfalls $(1200 \mathrm{~mm})$ the $A n$. gambiae $\mathrm{S}$ form predominated, comprising up to $70 \%$ of the total An. gambiae s.l. population [5,13]. More recently in Bobo-Dioulasso city An. arabiensis was observed as a high proportion (up to 50\%) of the total An. gambiae s.l. population and was identified at higher frequency than either $A n$. gambiae s.s. forms [12]. These results were not in accordance with those of Robert et al. [14] and Diabaté et al. [15] who reported that the An. gambiae S form comprised more than $80 \%$ of the malaria vector population of BoboDioulasso city. Taken together the sampling results in Bobo-Dioulasso city suggest that $A n$. arabiensis populations may be gradually increasing in this area which was previously dominated by An. gambiae s.s. To investigate this possibility further the present study aims i) to describe the population dynamics of species within the An. gambiae complex occurring in Bobo-Dioulasso, ii) to update their insecticide resistance status and finally iii) to estimate the Plasmodium infection rates within these vector populations in two representative quarters of Bobo-Dioulasso with different environmental conditions.

\section{Methods}

\section{Study areas}

The study was carried out at two sites of Bobo-Dioulasso: Dioulassoba $\left(11^{\circ} 10^{\prime} 42^{\prime \prime} \mathrm{N} ; 4^{\circ} 17^{\prime} 35^{\prime \prime} \mathrm{W}\right)$, located in the center of the city and Kodéni $\left(11^{\circ} 10^{\prime} \mathrm{N} ; 4^{\circ} 15^{\prime} \mathrm{W}\right)$, located on the outskirts of the city. The two study sites represent two major environmental niches of the city characterised by the presence of vegetable cropping and the Houet stream. The Houet stream is a year-long flowing water source running through Dioulassoba whereas Kodeni is mostly characterised by temporary and semipermanent wells created by small vegetable producers. The annual rainfall ranges from 1,000 to $1,200 \mathrm{~mm}$.

\section{Mosquito collections}

Specimens of An. gambiae s.l. were collected as adults and larvae in the two sites from May to December 2008. Larval stages were sampled from water bodies including, gutters and vegetable irrigation wells disseminated throughout the quarters and along the river Houet. Larval field collections were transferred to the laboratory for adult emergence and were then pooled. Adult An. gambiae mosquitoes were collected with other culicids by indoor spraying of aerosol insecticides early in the morning between 6,00-8,00 ha.m. in four houses during four consecutive days. They were then visually sorted from other anophelines according to morphological identification keys [16] and kept at $-20^{\circ} \mathrm{C}$ for molecular and ELISA analysis.

\section{Estimation of the Plasmodium infection rates}

The sporozoite infection rate of An. gambiae s.l. females collected indoors from May to December 2008 was estimated using the ELISA CSP technique [17].

\section{Insecticide susceptibility test}

Insecticide susceptibility tests were performed on 2-3day-old An. gambiae s.l. females using the WHO standard vertical tube protocol. Four insecticide-impregnated papers were used: $0.75 \%$ permethrin (cis:trans $=25: 75$ ), $0.05 \%$ deltamethrin, $0.1 \%$ bendiocarb and $4 \%$ DDT. The insecticide susceptibility status of wild-caught mosquitoes was compared with that of the "Kisumu" laboratory reference strain, which is fully susceptible to insecticides. Controls included "Kisumu" and wild-caught mosquitoes exposed to papers treated with solvent only. After $1 \mathrm{~h}$ exposure, mosquitoes were transferred into insecticide free tubes and maintained on sucrose solution. Final mortality was recorded $24 \mathrm{~h}$ after exposure. The threshold of susceptibility/resistance was fixed at $98 \%$ survivorship for the four insecticides according to the World Health Organisation (WHO) guidelines [18]. Dead and survivor mosquitoes were grouped separately and stored on silica gel at $-20^{\circ} \mathrm{C}$ for subsequent PCR analysis. 


\section{Molecular analysis}

Genomic DNA was extracted from individual mosquitoes according to a slightly modified version of the procedure described by Collins and others [19]. After quantification of the extracted DNA, adults of An. gambiae s.l. including indoor spray catches tested in ELISA -CSP and samples of those tested in bioassay were processed by PCR for molecular identification of species and molecular form as described previously $[20,21]$. Bioassay survivors and those samples that died following exposure to each of the insecticides were further processed using additional PCR assays for the detection of $k d r$ and $a c e-1^{R}$ alleles according to standard protocols $[22,23]$.

\section{Statistical analysis}

The frequency of each species, molecular form and sporozoite infection rates were compared between the two sites by chi-squared test. The frequency of the $k d r$ mutation was calculated according to the formula $p=2 \mathrm{AA}+\mathrm{Aa} / 2 \mathrm{n}$ where AA was the number of homozygotes, Aa the number of heterozygotes and $n$ the size of specimens analysed. As the sample size was sometimes too low to give reliable estimates of $k d r$ and ace- $1^{R}$ frequency for each species or molecular form, we pooled all specimens (resistant and susceptible to DDT, pyrethroids and bendiocarb) prior to allele frequency determination. The genotypic differentiation of $k d r$ loci in An. gambiae s.l. populations was tested using the Fischer exact test implemented in GenePop (ver.3.4) software [24].

\section{Results}

Species composition, vector dynamics, and vectorial role of An. arabiensis in Kodeni and Dioulassoba

In total 1166 and 1119 mosquitoes were collected by indoor spraying of insecticide aerosol in Kodeni and Dioulassoba respectively from May to December 2008. Anopheles mosquitoes comprised a relatively low proportion of the total culicid collections in Kodeni and Dioulassoba (35.6\% and 27\% respectively). Of these, $A n$. gambiae s.l., was identified at the highest frequency $A n$. funestus with An. rufipes representing less than 1\%. The other culicids were composed exclusively of Culex quinquefasciatus, which reached $64.3 \%$ and $73 \%$ of the total collections at Kodeni and Dioulassoba respectively.

\section{Temporal population dynamics of An. gambiae s.l. and molecular forms at the two sites}

In Kodeni the An. gambiae S form and An. arabiensis were the major species observed during the study period (Figure 1). Except for the first four months, they were collected in similar numbers. An. gambiae S form was found at higher frequency in May and August averaging 51 and $56 \%$ of collections vs 30\% for An. arabiensis. In June and July An. arabiensis was more frequent peaking maximally in June. Throughout all months An. gambiae M form was found as a low proportion of total collections and was always less than $20 \%$ in any month (Figure 1 ). In contrast, in Dioulassoba regardless of the month An. arabiensis was always found at the highest frequency comprising up to $100 \%$ of collections in certain months (Figure 2). An. gambiae $\mathrm{M}$ form was only observed in collections during four months (May, June, August and September) where it comprised less than $5 \%$ of the monthly collection. The An. gambiae $\mathrm{S}$ form was collected in July, August and September, also at relatively low frequency (comprising less than $4 \%$ of the monthly collection) (Figure 2). Overall An. arabiensis was the major species sampled in Bobo-Dioulasso city during the study period.

\section{Sporozoite rates}

Overall 658 An. gambiae s.l. females from the two study sites were analysed by ELISA CSP for infection with Plasmodium falciparum (Table 1). The mean infection rate (IR) was significantly higher in Kodeni (4.05\%) than Dioulassoba $(1.04 \%) \quad\left(\chi^{2}=4.05 ; \mathrm{ddl}=1, P<0.05\right)$. The infection rate was similar for An. arabiensis (6.2\%) and An. gambiae S form (4.2\%) in Kodeni with none of the, albeit smaller number of, An. gambiae $\mathrm{M}$ form mosquitoes infected. In Dioulassoba only a low percentage (1.4\%) of An. arabiensis females were infected with none of the small number of An. gambiae $\mathrm{M}$ and $\mathrm{S}$ form mosquitoes tested infected. The highest percentage of infected females was found during October at the two sites (12/180 tested) although in Kodeni a few additional infected mosquitoes were observed in August and December.

\section{Susceptibility of An. gambiae s.l. populations to insecticides}

Mortality rates were recorded 24 hours after the specimens were exposed to four insecticides: DDT, permethrin, deltamethrin and bendiocarb. The mortality rate in the control population was always $0 \%$, therefore, Abbot's correction was not necessary during data analysis. An. gambiae s.l. populations at the two sites were classified as resistant to DDT with mortality rates ranging from 18 to $58 \%$ (Table 2). In Kodeni the mortality rates of $A n$. gambiae s.l. recorded in September 2008 were 85\%, 94\%, $86 \%$ respectively for permethrin, deltamethrin and bendiocarb corresponding to an intermediary status of resistance according to WHO guidelines [18]. The resistance was confirmed in November 2008 where low mortality rates ranging from $40 \%$ to $73 \%$ were recorded for the four insecticides. In Dioulassoba, An. gambiae s.l. populations exhibited an intermediary level of resistance to permethrin and deltamethrin in September and November and an intermediate level of resistance to bendiocarb in September (Table 2). PCR was used to assign $A n$. 

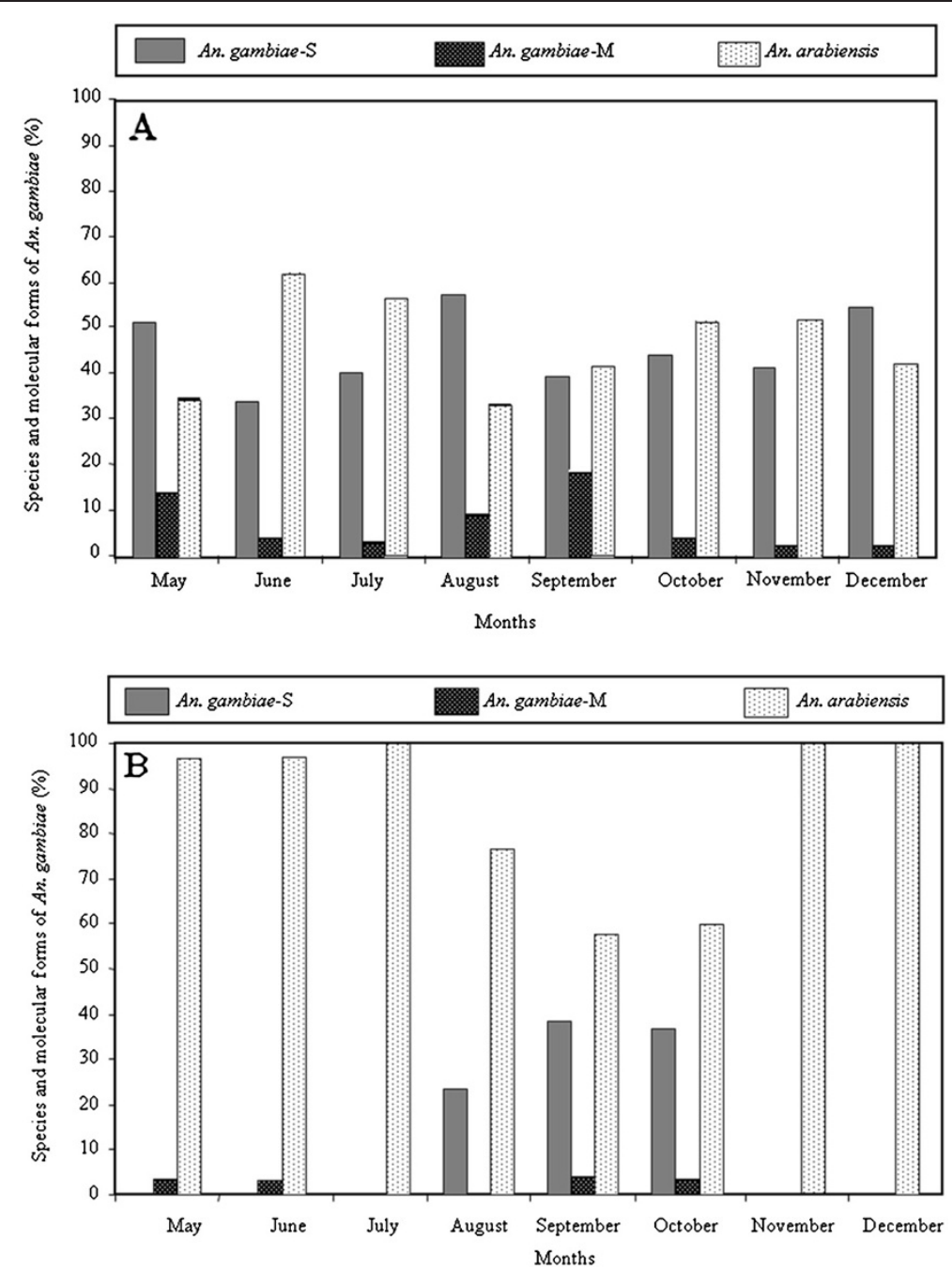

Figure 1 Monthly population dynamics of Anopheles gambiae s.l. in Kodeni.

gambiae s.l. that had survived or died in insecticide bioassays to species and molecular form (Table 3). This indicated that $A n$. arabiensis populations at both sites were resistant to DDT (50\% to $61 \%$ mortality), had an intermediate level of resistance to the pyrethroids, permethrin and deltamethrin ( $73 \%$ to $96 \%$ mortality) but were susceptible to bendiocarb. An. gambiae $\mathrm{S}$ form mosquitoes collected from both sites showed higher levels of resistance to all four insecticides than $A n$. arabiensis (0-46\% mortality to DDT, $51-73 \%$ mortality to the pyrethroids and $38-69 \%$ mortality to bendiocarb). An. gambiae M form mosquitoes collected from Kodeni were resistant to DDT but fully susceptible to bendiocarb, however, the number of $\mathrm{M}$ form mosquitoes collected was too low to assess their resistance status to the two pyrethroids in Kodeni or indeed to any insecticide at Dioulassoba (Tables 3, 4 and 5).
Frequency of the $k d r$ mutation (L1014F) in An. gambiae s.l. populations

The frequency of the $k d r$ mutation was not directly compared to resistance (as determined by insecticide exposure assays), in this study as to maximize the sample size for each species specimens that had survived or died upon exposure to pyrethroids and DDT were pooled. In total 586 specimens including resistant and susceptible mosquitoes exposed to DDT, permethrin and deltamethrin were tested. The $k d r$ mutation (L1014F) was found at high frequency (0.92) in An. gambiae s.s. S form specimens from both sites (Table 2). The $k d r$ mutation was observed at lower frequency $(\sim 0.5)$ in $\mathrm{M}$-form specimens and was found at similar frequency in the populations at both sites, however, the sample size for this species was relatively low. The $k d r$ mutation was not identified in An. arabiensis from either site. The S-form populations from both sites showed 


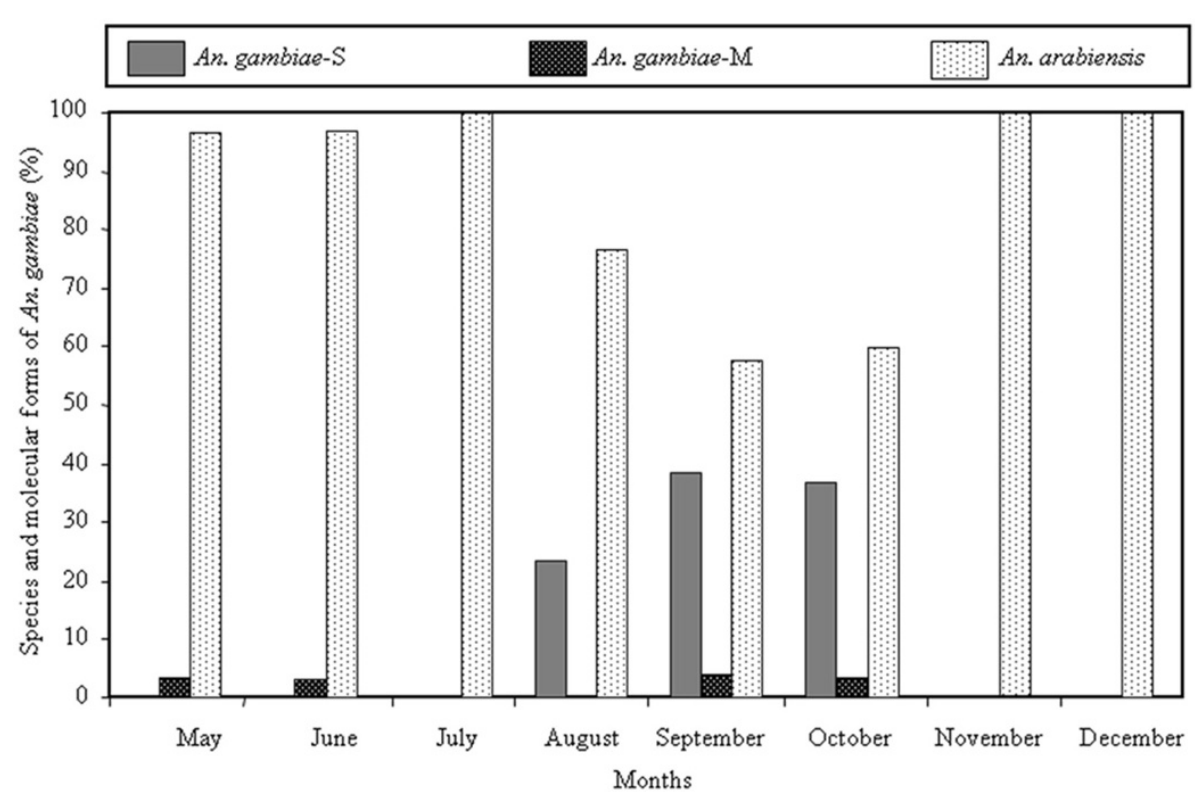

Figure 2 Monthly population dynamics of Anopheles gambiae s.l. in Dioulassoba.

a higher than expected number of individuals homozygous for the $k d r$ mutation rejecting Hardy-Weinberg equilibrium at these sites $(P=0.013 \& P=0.001$ respectively in Kodeni and Dioulassoba).

Frequency of the ace- $1^{R}$ mutation in An. gambiae s.l. Overall 105 specimens of An. gambiae s.l. exposed to bendiocarb including 18 resistant and 87 susceptible mosquitoes were analysed by PCR in Kodeni for the detection of the ace- $1^{R}$ mutation (G119). The mutation was detected in 17 of the 18 resistant specimens (16 heterozygous 1 homozygous, a frequency of 0.53 ). All of the specimens carrying the ace- $1^{R}$ mutation were of the An. gambiae s.s. S form.

In Dioulassoba, of 87 specimens of An. gambiae s.l. the ace- $1^{R}$ mutation was only identified within $A n$. gambiae s.s. $\mathrm{S}$ form individuals at a frequency of 0.29 with 1 homozygous and 8 heterozygous individuals. All individuals that survived bendiocarb exposure carried both the $k d r$ and $a c e-1^{\mathrm{R}}$ mutations and were homozygous for the $k d r$ mutation. No An. arabiensis was identified carrying the ace- $1^{R}$ mutation at either site.

Sample numbers were sufficient to compare ace- $1^{R}$ gene frequencies with Hardy-Weinberg expectations in populations collected from the two sites (when $n=14$ or greater).
The observed genotypic frequencies were not significantly different from Hardy-Weinberg expectations at the 95\% confidence level in populations from either site (Table 3).

\section{Discussion}

The An. gambiae complex is composed of at least seven morphologically indistinguishable species $[1,25]$ throughout sub-Saharan Africa including neighbouring islands. Among them only An. gambiae s.s. and An. arabiensis are found in Burkina Faso. These species are sympatric in the major parts of the country but the relative frequency of the two species varies in rural and urban areas. Previously, Coluzzi and others [25] reported penetration of $A n$. arabiensis into towns and cities of the rainy forest zone in southern Nigeria. Kristan and others [26] reported a similar trend among samples of An. gambiae s.l., in the urban localities of Aiyetoro and Lantoko of Nigeria where the majority of the vector population was identified as An. arabiensis. Although Lemasson and others [27], showed that An. arabiensis had a lower vectorial capacity than $A n$. gambiae s.s. in Senegal, these results imply an extension/adaptation of this species into/to urban areas. Studies in more locations are needed to further confirm and understand what may be

Table 1 Sporozoite rate calculated in An. gambiae s.l. collected from Kodeni and Dioulassoba by indoor insecticide aerosol spray (number in bracket is the percentage of infection)

\begin{tabular}{|c|c|c|c|c|c|c|c|c|}
\hline \multirow[t]{2}{*}{ Locality } & \multicolumn{2}{|c|}{ An. gambiae $S$} & \multicolumn{2}{|c|}{ An. gambiae $M$} & \multicolumn{2}{|c|}{ An. arabiensis } & \multirow{2}{*}{$\begin{array}{c}\text { Total } \\
\text { tested }\end{array}$} & \multirow[t]{2}{*}{ IR } \\
\hline & Nb tested & IR & Nb tested & IR & Nb tested & IR & & \\
\hline Kodeni & 191 & $8[4.2]$ & 66 & 0 & 113 & 7 [6.19] & 370 & 15 [4.05] \\
\hline Dioulassoba & 52 & 0 & 24 & 0 & 212 & 3 [1.4] & 288 & $3[1.04]$ \\
\hline
\end{tabular}


Table 2 Mortality rates of An. gambiae s.l. collected from Kodeni and Dioulassoba exposed to 4\% DDT, $0.75 \%$ permethrin, $0.05 \%$ deltamethrin and $0.1 \%$ bendiocarb respectively

\begin{tabular}{|c|c|c|c|c|c|c|c|c|}
\hline \multirow[t]{3}{*}{ SITE } & \multicolumn{8}{|c|}{ INSECTICIDE } \\
\hline & \multicolumn{2}{|c|}{$4 \%$ DDT } & \multicolumn{2}{|c|}{$0.75 \%$ Permethrin } & \multicolumn{2}{|c|}{$0.05 \%$ Deltamethrin } & \multicolumn{2}{|c|}{$0.1 \%$ Bendiocarb } \\
\hline & $\mathbf{N}$ & Mortality\% & $\mathbf{N}$ & Mortality\% & $\mathbf{N}$ & Mortality \% & $\mathbf{N}$ & Mortality\% \\
\hline \multicolumn{9}{|l|}{ Kodeni } \\
\hline September 08 & 100 & $43( \pm 2.06)$ & 109 & $85.3( \pm 4.3)$ & 101 & $94( \pm 0.5)$ & 102 & $86.2( \pm 3.1)$ \\
\hline November 08 & 105 & $40.1( \pm 0.57)$ & 102 & $40.1( \pm 0.95)$ & 98 & $73.4( \pm 1.4)$ & 81 & $70.3( \pm 1)$ \\
\hline \multicolumn{9}{|l|}{ Dioulassoba } \\
\hline September 08 & 108 & $18.5( \pm 1.14)$ & 95 & $68.4( \pm 6.1)$ & 100 & $94( \pm 1.73)$ & 114 & $85( \pm 0.95)$ \\
\hline November 08 & 124 & $58( \pm 2.1)$ & 107 & $88.7( \pm 2.5)$ & 121 & $81.8( \pm 2.75)$ & 97 & $100( \pm 3.05)$ \\
\hline
\end{tabular}

driving the expansion of An. arabiensis in West African cities. An. arabiensis is the most widespread species among the members of the An. gambiae complex and is the most adaptive in respect to feeding and resting choices [28,29]. In 1986, Robert and others [14] studying malaria transmission in Bobo-Dioulasso city including Dioulassoba (the same site as the present study) identified only $3 \%$ of the mosquito malaria vector population

Table 3 PCR identification of species and molecular form of An. gambiae s.l. mosquitoes collected from Kodeni and Dioulassoba and tested in insecticide exposure assays

\begin{tabular}{|c|c|c|c|c|}
\hline Sites & An. gambiae s.I.N tested in PCR & An. gambiae $\mathrm{S}$ & An. gambiae M & An. arabiensis \\
\hline \multicolumn{5}{|l|}{ Kodeni } \\
\hline \multicolumn{5}{|l|}{$4 \%$ DDT } \\
\hline September 08 & 52 & $\mathbf{8}(7)[46 \%]$ & 15(9) [38\%] & $\mathbf{5}(8)[61 \%]$ \\
\hline November 08 & 30 & $20(0)[0 \%]$ & $1(0)$ & $\mathbf{1}(8)$ \\
\hline \multicolumn{5}{|c|}{$0.75 \%$ Permethrin } \\
\hline September 08 & 106 & 30(32) [51\%] & 6(1) & $\mathbf{6}(31)[83 \%]$ \\
\hline November 08 & 42 & $11(10)[48 \%]$ & $\mathbf{0}(0)$ & $\mathbf{2}(19)[90 \%]$ \\
\hline \multicolumn{5}{|c|}{ 0.05\% Deltamethrin } \\
\hline September 08 & 101 & $15(30)[67 \%]$ & $\mathbf{0}(1)$ & 2(53) [96\%] \\
\hline November 08 & 41 & $\mathbf{4}(11)[73 \%]$ & $\mathbf{3}(0)$ & $\mathbf{4}(19)[83 \%]$ \\
\hline \multicolumn{5}{|c|}{ 0.1\% Bendiocarb } \\
\hline September 08 & 75 & 16(10) [38\%] & $\mathbf{0}(14)[100 \%]$ & $\mathbf{0}(35)[100 \%]$ \\
\hline November 08 & 32 & $4(6)[60 \%]$ & $\mathbf{0}(0)$ & $\mathbf{0}(22)[100 \%]$ \\
\hline \multicolumn{5}{|l|}{ Dioulassoba } \\
\hline \multicolumn{5}{|l|}{$4 \%$ DDT } \\
\hline September 08 & 61 & $13(0)[0 \%]$ & $\mathbf{0}(1)$ & 19(28) [60\%] \\
\hline November 08 & 40 & $0(0)$ & $0(0)$ & $20(20)[50 \%]$ \\
\hline \multicolumn{5}{|c|}{ 0.75\% Permethrin } \\
\hline September 08 & 77 & 16(22) [58\%] & $\mathbf{0}(2)$ & $\mathbf{5}(32)[86 \%]$ \\
\hline November 08 & 30 & 0 & 0 & $8(22)$ [73\%] \\
\hline \multicolumn{5}{|c|}{$0.05 \%$ Deltamethrin } \\
\hline September 08 & 63 & 13(18) [58\%] & 2(4) & $\mathbf{1}(25)[96 \%]$ \\
\hline November 08 & 36 & $\mathbf{0}(0)$ & $\mathbf{0}(0)$ & 6(30) [83\%] \\
\hline \multicolumn{5}{|c|}{$0.1 \%$ Bendiocarb } \\
\hline September 08 & 67 & $\mathbf{5}(11)[69 \%]$ & $\mathbf{0}(0)$ & $\mathbf{1}(50)[98 \%]$ \\
\hline November 08 & 34 & $\mathbf{0}(0)$ & $\mathbf{0}(0)$ & $\mathbf{0}(34)[100 \%]$ \\
\hline
\end{tabular}

$\mathrm{N}=$ number of samples tested in PCR; numbers in bold represent the number of survivors; numbers in italics represent the number of specimens that died; the figure in square brackets represents the percentage mortality for each species or molecular form when $n \geq 10$. 
Table 4 Frequency of the kdr L1014F mutation in An. gambiae s.l. from Kodeni and Dioulassoba that were tested against $4 \%$ DDT and pyrethroids $(0.75 \%$ permethrin and $0.05 \%$ deltamethrin)

\begin{tabular}{|c|c|c|c|c|c|c|c|}
\hline Locality & Species & $\mathrm{N}$ & SS & RS & RR & $F(k d r)$ & HW (P-value)* \\
\hline \multirow[t]{3}{*}{ Kodeni } & An. arabiensis & 127 & 127 & 0 & 0 & 0 & - \\
\hline & An. gambiae -M & 22 & 8 & 8 & 6 & 0.45 & - \\
\hline & An. gambiae -S & 145 & 3 & 16 & 126 & 0.92 & 0.013 \\
\hline \multirow[t]{3}{*}{ Dioulassoba } & An. arabiensis & 208 & 208 & 0 & 0 & 0 & - \\
\hline & An. gambiae -M & 8 & 4 & 0 & 4 & 0.5 & 0.03 \\
\hline & An. gambiae -S & 76 & 5 & 1 & 70 & 0.92 & 0.001 \\
\hline
\end{tabular}

$\mathrm{F}(k d r)$ values $=$ frequencies of the $k d r$ mutation. $\mathrm{HW}=$ Hardy-Weinberg test.

*The exact probability for rejecting Hardy-Weinberg equilibrium.

The genotype of each mosquito specimen tested is also shown.

as An. arabiensis. In 1999, Chandre and others [30] failed to identify any $A n$. arabiensis in the same area. In 2002, Diabaté and others recorded that the malaria vector population in Dioulassoba was composed of $8.3 \%$ An. arabiensis [15]. Our results show the advanced infiltration of An. arabiensis into this district where its proportion of the total vector composition now reaches $90 \%$ whatever the sampling period. The same situation has also been observed in Kodeni, a peripheral district of the city ( $>50 \%$ An. arabiensis vs $40 \%$ An. gambiae s.s.). According to a recent study, An. arabiensis was also reported as the dominant vector in the savannah around Bobo-Dioulasso city suggesting that this infiltration now extends beyond Bobo-Dioulasso [31]. Indeed, while the frequency and distribution of An. arabiensis appears to be growing, the role of secondary vectors such as Anopheles nili which had previously played a local but important role in malaria transmission in rural areas surrounding Bobo-Dioulasso seems to be greatly reduced [11]. The pattern of An. arabiensis expansion in this region could be explained by global ecological changes (such as climate change) or local human activities favouring the colonisation of this species, however, further investigation is needed to examine these two possibilities further. The trend identified in our study and those of others appears to be mirrored in the capital of Burkina Faso, Ouagadougou, where An. gambiae s.s. was formerly reported as the major vector species $[32,33]$. However, recently An. arabiensis has been described as the predominant vector species in this city (55\% An. arabiensis vs $45 \%$ for the An. gambiae M form) [9]. In An. gambiae M and S forms adaptation to different ecological niches is associated with specific chromosomal inversions that appear to confer on the $\mathrm{M}$ form traits that allow exploitation of flooded and arid areas and make the $S$ form significantly rain dependant $[4,34]$. However, more investigation is needed to understand the genetic basis underlying the adaptation of An. arabiensis either to the humid meridian savannah or to polluted sites in urban areas as seems to be the case in our study.

Considering the changing pattern of vector bionomics in Bobo-Dioulasso over the last decade or so it might be assumed that the malaria transmission potential has altered. In 1986, a low annual entomological inoculation rate (EIR) of 0.19 infected bites per year (i/b/y) in Dioulassoba and 4.6 $\mathrm{i} / \mathrm{b} / \mathrm{y}$ in peripheral districts had been reported [14]. In 2003 Diabaté (unpublished data) recorded higher inoculation rates reaching $57 \mathrm{i} / \mathrm{b} / \mathrm{y}$ in Dioulassoba and $63 \mathrm{i} / \mathrm{b} / \mathrm{y}$ in peripheral districts. In the current study our sampling technique did not allow the EIR to be estimated with any accuracy. However, taking into account mosquito infection rates alone it is possible that the transmission intensity may not have changed greatly from that formerly reported in 2003 by Diabaté (unpublished data).

Table 5 Frequency of the ace- $1^{R}$ allele in An. gambiae s.l. from Kodeni and Dioulassoba tested against $0.1 \%$ bendiocarb. The genotype of each mosquito specimen is also shown

\begin{tabular}{|c|c|c|c|c|c|c|c|}
\hline Locality & Species & $\mathbf{N}$ & SS & RS & RR & $F\left(\right.$ ace $\left.-1^{R}\right)$ & HW (P-value)* \\
\hline \multirow[t]{3}{*}{ Kodéni } & An. arabiensis & 57 & 57 & 0 & 0 & 0 & - \\
\hline & An. gambiae -M & 14 & 14 & 0 & 0 & 0 & - \\
\hline & An. gambiae -S & 39 & 16 & 22 & 1 & 0.3 & 0.999 \\
\hline \multirow[t]{3}{*}{ Dioulassoba } & An. arabiensis & 70 & 70 & 0 & 0 & 0 & - \\
\hline & An. gambiae -M & 0 & 0 & 0 & 0 & 0 & - \\
\hline & An. gambiae -S & 17 & 8 & 8 & 1 & 0.29 & 0.843 \\
\hline
\end{tabular}


To test the susceptibility of these urban vector populations to insecticides we exposed them to the most commonly used insecticides for public heath purposes and also to DDT. The frequency of two common resistance mechanisms in these populations, $k d r$ and $a c e-1^{R}$, that confer resistance to pyrethroids/DDT and organophosphates/ carbamates respectively was also examined. Taking the $A n$. gambiae s.l. population as a whole, resistance was observed to pyrethroids, bendiocarb and most significantly to DDT at both sites. The An. gambiae S form showed the highest levels of resistance to all four insecticides and this was consistent with the high frequency of $k d r / a c e-1^{R}$ observed in this molecular form, the former of which appears to be approaching fixation. Because of the relative rarity of the An. gambiae $\mathrm{M}$ form it was not possible to assess its resistance status to all insecticides, however, it showed clear resistance to DDT but was fully susceptible to bendiocarb, consistent with a frequency of $\sim 0.5$ for $k d r$ and an absence of ace- $1^{R}$. An. arabiensis populations also showed resistance to DDT, modest levels of resistance to pyrethroids, and were fully susceptible to bendiocarb. In contrast to the An. gambiae $\mathrm{S}$ form the L1014F $k d r$ mutation was not found in An. arabiensis suggesting that other mechanism(s) underlie resistance to DDT/pyrethroids. It would therefore be interesting in future to investigate the role of detoxifying enzymes such as esterases, cytochrome P450s and glutathione-s-transferases in resistance. No An. arabiensis was found to carry the ace- $1^{R}$ mutation correlating with the results of bioassays showing that An. arabiensis remains susceptible to carbamate compounds.

The resistance level observed in An. gambiae s.s. at the two sites may be partly explained by the use of insecticides for crop protection in Kodeni where farmers apply large amounts of insecticides for vegetable production and the domestic use of insecticides such as aerosol sprays or coils in Dioulassoba. In 1993 in Bouaké, Côte d'Ivoire, the presence of permethrin resistance was attributed to widespread use of pyrethroids in households [35].

In this study An. gambiae s.s. mosquitoes carrying both $k d r$ and ace- $1^{R}$ mutations were identified in the field. The presence of both these resistance mechanisms in An. gambiae s.s. from the West of Burkina Faso has been reported previously and would be expected to provide a level of protection to pyrethroids, carbamates and organophosphates [36]. Presently, pyrethroid treated bednets alone or combined with indoor residual spraying remain the primary mechanism to control malaria vectors in these regions. An essential component of effective vector management strategies is the monitoring of vector populations for resistance to the insecticides used for control and the frequency and distribution of mechanism(s) underlying resistance. The data our study provides is therefore useful contemporary information for vector control programmes in Bobo-Dioulasso city.

\section{Conclusion}

This study demonstrates that the population dynamics of malaria vectors in one area can change with time, possibly in response to climate change or human activities. However, changes in these populations may not necessarily significantly impact malaria transmission. Our study confirms that An. arabiensis, formerly comprising a low percentage of the vector population in the south of the country, is replacing An. gambiae s.s. as the major vector species in Bobo-Dioulasso city and the savannah villages surrounding the city. This change in vector composition occurring in many parts of Africa is not new but is important as it has significant potential impacts for vector control strategies $[37,38]$. For example, $A n$. arabiensis has been shown to be more exophilic than An. gambiae s.s. and this can reduce the effectiveness of vector control interventions that specifically target endophilic and anthropophilic species.

\section{Competing interest}

The authors declare no competing interest.

\section{Authors' contribution}

RKD participated in the study design, supervised the field study, analysed the data and wrote the paper. MN participated in conducting bioassays performed in the laboratory and related data analysis. LBY and AO participated in sample collection and analysis in the laboratory. HKT participated in the molecular analysis in the lab. SPS participated in the statistical analysis. FS, FC, LCG and TB and CB participated in the drafting and the revision to the paper. AD participated in the manuscript drafting. All authors approved the final version of the manuscript.

\section{Acknowledgements}

The authors thank the inhabitants of Dioulassoba and Kodeni for their sincere cooperation during mosquitoes sampling and larva collection. The study was partially supported by CORUS 6015 and MIM 60098A for the bioassays and molecular analysis of the specimens respectively.

\section{Author details}

${ }^{1}$ Institut de Recherche en Sciences de la Santé/Centre Muraz, 01 BP 390 Bobo-Dioulasso 01, Burkina Faso. ${ }^{2}$ RDD/UR016-CRVOI, 2 rue Maxime Rivière 97490, Sainte Clotilde, lle de la Réunion, Montpellier, Cedex 5, France. ${ }^{3}$ RSSS/ UMR MIVEGEC/IRD, BP 545 Bobo-Dioulasso, Burkina Faso. ${ }^{4}$ LIN-IRD/UMR MIVEGEC, BP 64501, 34394 Montpellier, Cedex 5, France. ${ }^{5}$ Centre Entomologique de Cotonou/IRD/CIRAD, 06 BP 2604 Cotonou, République du Bénin Cotonou, Bénin. 'Biological Chemistry and Crop Protection, Rothamsted Research, Harpenden AL5 2JQ, UK.

Received: 29 February 2012 Accepted: 30 May 2012

Published: 21 June 2012

\section{References}

1. Hunt RH, Coetzee M, Fettene M: The Anopheles gambiae complex: A new species from Ethiopia. Trans R Soc Trop Med Hyg 1998, 92:231-235.

2. Della Torre A, Tu Z, Petrarca V: On the distribution and genetic differentiation of Anopheles gambiae ss molecular forms. Insect Bioch Mol Biol 2005, 35:7055-7069.

3. Govella NJ, Chaki PP, Mpangile JM, Gerry F, Killeen GF: Monitoring mosquitoes in urban Dar es Salaam: Evaluation of resting boxes, window exit traps, CDC light traps, Ifakara tent traps and human landing catches. Parasites \& Vectors 2011, 4:40.

4. Touré YT, Petrarca V, Traoré SF, Coulibaly A, Maiga HM, Sangaré O, Sow M, Di Decco MA, Coluzzi M: The distribution and inversion polymorphism of chromosomally recognised taxa of the Anopheles gambiae complex in Mali, West Africa. Parassitologia 1998, 40:477-511. 
5. Costantini C, Ayala D, Guelbeogo WM, Pombi M, Some CY, Bassole $I H N$, Ose K, Fotsing JM, Sagnon NF, Fontenille D, Besansky N, Simard F: Living at the edge: biogeographic patterns of habitat segregation conform to speciation by niche expansion in Anopheles gambiae. BMC Ecol 2009, 9:16. doi:10.1186/1472-6785-9-16.

6. Trape JF, Lefebvre-Zante E, Legros F, Ndiaye G, Bouganali $H$, Druilhe $P$, Salem G: Vector density gradients and the epidemiology of urban malaria in Dakar, Senegal. Am J Trop Med Hyg 1992, 47:181-189.

7. Robert V, Awono-Ambene HP, Thioulouse J: Ecology of larval mosquito, with special reference to Anopheles arabiensis (Diptera: Culicidae) in market-garden wells in the urban area of Dakar, Senegal. J Med Entomol 1998, 35:948-955.

8. Dongus S, Nyika D, Kannady K, Mtasiwa D, Mshinda H, Fillinger U, Drescher AW, Tanner M, Castro MC, Killeen GF: Participatory mapping of target areas to enable operational larval source management to suppress malaria vector mosquitoes in Dar es Salaam, Tanzania. Int J Health Geogr 2007, 6(1):37.

9. Fournet F, Maud C, Ouari A, Meyer P-E, Toé HK, Gouagna LC, Dabiré KR: Diversity in anopheline larval habitats and adult composition during the dry and wet seasons in Ouagadougou (Burkina Faso). Malaria J 2010, 9:78.

10. Robert V, Gazin P, Boudin C, Molez JF, Ouedraogo V, Carnevale P: The transmission of malaria in a wooded savannah area and a rice-growing area around Bobo-Dioulasso (Burkina Faso). Ann Soc Belg Med Trop 1985, 65:201-214

11. Dabiré KR, Baldet T, Diabaté A, Dia I, Costantini C, Cohuet A, Guiguemdé TR, Fontenille D: Anopheles funestus Giles, 1900 (Diptera: Culicidae) in a humid savannah area of western Burkina Faso: bionomics, insecticides resistance status and role in malaria transmission. J Med Entomol 2007, 44(Suppl 6):990-997.

12. Djogbenou L, Dabiré KR, Diabaté $A$, Kengne $P$, Akogbeto $M$, Hougard JM, Chandre F: Identification and geographical distribution of ace- $1^{R}$ mutation in the malaria vector Anopheles gambiae in south-western Burkina Faso, West Africa. Am J Trop Med Hyg 2008, 78:298-302.

13. Dabiré KR, Diabaté A, Namountougou M, Toé KH, Ouari A, Kengne P, Bass C, Baldet T: Distribution of pyrethroid and DDT resistance and the L1014F kdr mutation in Anopheles gambiae s.l. from Burkina Faso (West Africa). Trans R Soc Trop Med Hyg 2009, 103:1113-1120.

14. Robert V, Gazin P, Ouédraogo V, Carnevale P: Le paludisme urbain à BoboDioulasso (Burkina Faso). Cahiers ORSTOM Ser Ent Parasitol 1986, 24:121-128.

15. Diabaté A, Baldet T, Chandre F, Akogbeto M, Darriet F, Brengues $C$, Guiguemdé TR, Guillet P, Hemingway J, Hougard JM: The role of agricultural use of insecticides in resistance to pyrethroids in Anopheles gambiae sl in Burkina Faso. Am J Trop Med Hyg 2002, 67:617-622.

16. Gillies MT, Coetzee M: A supplement to the Anophelinae of Africa South of the Sahara (Afrotropical Region). Vol. 55. In Publications of the South African Institute of Medical Research, Johnenesburg, South Africa:; 1987:143.

17. Burkot TR, Williams $J \mathrm{~L}$, Scheinder I: Identification of Plasmodium falciparum infected- mosquitoes by a double antibody enzyme-linked immunosorbent assay. Am J Trop Med Hyg 1987, 33:783-788.

18. WHO: Test procedures for insecticides resistance monitoring in malaria vectors, bio-efficacy and persistence of insecticides on treated surfaces.: WHO/CDS/ MAL/98 12; 1998.

19. Collins FH, Mendez MA, Rasmussen MO, Mehaffey PC, Besansky NJ, Finnerty $\mathrm{V}$ : A ribosomal RNA gene probe differentiates member species of Anopheles gambiae complex. Am J Trop Med Hyg 1987, 37:37-41.

20. Scott JA, Brogdon WG, Collins FH: Identification of single specimens of $A n$. gambiae complex by polymerase chain reaction. Am J Trop Med Hyg 1993, 49:520-529.

21. Favia G, Lanfrancotti A, Spanos L, Sideén-Kiamos I, Louis C: Molecular characterization of ribosomal DNA polymorphisms discriminating among chromosomal forms of Anopheles gambiae ss. Insect Mol Biol 2001, 10:3-5.

22. Martinez-Torres D, Chandre F, Williamson MS, Darriet F, Berge JB, Devonshire AL, Guillet P, Pasteur N, Pauron D: Molecular characterization of pyrethroid knockdown resistance $(\mathrm{kdr})$ in the major malaria vector Anopheles gambiae ss. Insect Mol Biol 1998, 7:179-184.

23. Weill M, Malcolm C, Chandre F, Mogensen K, Berthomieu A, Marquine M, Raymond M: The unique mutation in ace-1 giving high insecticide resistance is easily detectable in mosquito vectors. Insect Mol Biol 2004, 13:1-7.
24. Rousset F, Raymond M: Testing heterozygotes excess and deficient. Genetics 1995, 140:1413-1419.

25. Coluzzi M, Sabatini A, Petrarca V, Di Deco MA: Chromosomal differentiation and adaptation to human environments in the Anopheles gambiae complex. Trans R Soc Trop Med Hyg 1979, 73:483-497.

26. Kristan M, Fleischmann H, Della Torre A, Stich A, Curtis CF: Pyrethroid resistance/susceptibility and differential urban/rural distribution of Anopheles arabiensis and An. gambiae ss malaria vectors in Nigeria and Ghana. Met Vet Entomol 2003, 17:326-332.

27. Lemasson JJ, Fontenille D, Lochouarn L, Dia I, Simard F, Ba K, Diop A, Diatta M, Molez JF: Comparison of behavior and vector efficency of Anopheles gambiae and An. arabiensis (Dipetra: Culidae) in Barkedji, a Sahelian area of Senegal. J Med Entomol 1997, 34:396-403.

28. Chauvet $\mathrm{G}$, Rajaonarivelo E: Modification de comportement d'une espèce et variation de la composition d'une population appartenant au complexe Anopheles gambiae pendant et après des pulvérisations d'insecticides domiciliaires dans les environs de Tananarive (Madagascar). Cahiers ORSTOM Sér Entomol Méd Parasitol 1973, 11(Suppl 3):155-167

29. Awolola TS, Oduola AO, Obansa JB, Chukwurar NJ, Unyimadu JP: Anopheles gambiae s.s. breeding in polluted water bodies in urban Lagos, southwestern Nigeria. J Vector Borne Dis 2007, 44:241-244.

30. Chandre F, Manguin S, Brengues C, Dossou-Yovo J, Darriet F, Diabaté A, Carnevale P, Guillet P: Status of pyrethroid resistance in Anopheles gambiae sensu lato. Bull World Health Organ 1999, 77:230-234.

31. Gimonneau G, Boyer J, Morand S, Besansky JN, Diabaté A, Simard F: A behavioral mechanism underlying ecological divergence in the malaria mosquito Anopheles gambiae. Behavioral Ecology 2010, 21:1087-1092.

32. Sabatinelli G, Rossi $P$, Belli A: Etude sur la dispersion d'An. gambiae dans la zone urbaine à Ouagadougou. Parassitologia 1986, 30:178-179.

33. Rossi P, Belli A, Mancini L, Sabatinelli G: Enquête entomologique longitudinale sur la transmission du paludisme à Ouagadougou, Burkina Faso. Parassitologia 1986, 28:1-15.

34. Touré YT, Petrarca V, Traoré SF, Coulibaly A, Maiga HM, Sangaré O, Sow M, Di Decco MA, Coluzzi M: Ecological genetics studies in the chromosomal form Mopti of Anopheles gambiae ss in Mali, West Africa. Genetica 1994, 94:213-223.

35. Elissa N, Mouchet J, Riviere F, Meunier JY, Yao K: Resistance of Anopheles gambiae ss to pyrethroids in Cote d'Ivoire. Ann Soc Bel Med Trop 1993, 73:291-294

36. Dabiré KR, Diabaté $A$, Namountougou M, Djogbenou L, Kengne $P$, Ouédraogo J-B, Simard F, Bass C, Baldet T: The distribution of insensitive acetylcholinesterase $\left(a c e-1^{R}\right)$ in Anopheles gambiae s.l. populations from Burkina Faso (West Africa). Trop Med Int Health 2009, 14(4):396-403.

37. Robert V, Macintyre K, Keating J, Trape JF, Duchemin JB, Warren M, Beier JC: Malaria transmission in urban sub-Saharan Africa. Am J Trop Med Hyg 2003, 68:169-176.

38. White MT, Griffin JT, Churcher TS, Ferguson NM, Basáñez MG, Ghani AC: Modelling the impact of vector control interventions on Anopheles gambiae population dynamics. Parasites \& Vectors 2011, 4:153.

doi:10.1186/1756-3305-5-127

Cite this article as: Dabiré et al:: Population dynamics of Anopheles gambiae s.l. in Bobo-Dioulasso city: bionomics, infection rate and susceptibility to insecticides. Parasites \& Vectors 2012 5:127.

\section{Submit your next manuscript to BioMed Central and take full advantage of:}

- Convenient online submission

- Thorough peer review

- No space constraints or color figure charges

- Immediate publication on acceptance

- Inclusion in PubMed, CAS, Scopus and Google Scholar

- Research which is freely available for redistribution 